\title{
Measured Energy Savings \\ from Using \\ Night Temperature Setback
}

\author{
R. F. Szydlowski \\ L. E. Wrench \\ P. J. O'Neill \\ J. B. Paton ${ }^{(\omega)}$
}

January 1993

Prepared for

the U.S. Department of Energy

Federal Energy Management Program

under Contract DE-AC06-76RLO 1830

Pacific Northwest Laboratory

Richland, Washington 99352

(a) Fort Devens, Massachusetts

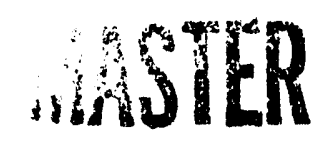




\section{Preface}

The goal of the U.S. Department of Energy Federal Energy Management Program (FEMP) is to facilitate energy-efficiency improvements at federal facilities. This is accomplished by a balanced program of technology development, facility assessment, and use of cost-sharing procurement mechanisms. Technology development focuses upon the tools and procedures used to identify and evaluate efficiency improvements. For facility assessment, FEMP provides metering equipment and trained analysts to federal agencies exhibiting a commitment to improve energy-use efficiency. To assist in implementing energy-efficiency measures, FEMP helps federal agencies with identifying efficiency opportunities and in implementing energy-efficiency and demand-side management programs at federal sites.

As the lead laboratory for FEMP, Pacific Northwest Laboratory (FNL) provides technical assistance to federal agencies to better understand and characterize energy systems. The U.S. Army Forces Command (FORSCOM) has tasked PNL to provide technical assistance to characterize and modernize energy systems at FORSCOM installations. In response to a request from the Fort Devens Directorate of Logistics, PNL conducted a field test at the Fort during the 1991-1992 winter to measure the energy savings resulting from installation of automatic night-setback thermostats. An overview of that field test is presented in this report. 


\section{Summary}

The measured energy savings resulting from using night temperature setback in typical lightconstruction wooden office buildings was determined. Researchers installed monitoring equipment in a six-building sample of two-story wooden buildings at Fort Devens, Massachusetts. Data obtained during both single-setting and night-setback operating modes were used to develop models of each building's heat consumption as a function of the difference between inside and outside temperature. These models were used to estimate seasonal savings that could be obtained from the use of nightsetback thermostat control.

The measured savings in heating energy from using night temperature setback for the six Fort Devens buildings ranged from $14 \%$ to $25 \%$; the mean savings was $19.2 \%$. Based on an energy cost of $\$ 0.65 /$ therm of natural gas, the estimated average cost savings of using automatic setback thermostats in these buildings is $\$ 780$ per year per building. 


\section{Acknowledgments}

The authors would like to thank Bobby Orr and his staff at the Fort Devens Directorate of Engineering and Housing for their support in installing the automatic setback thermostats.

Appreciation is extended to PNL staff whose efforts supported the study: John Schmelzer for monitoring equipment preparation and installation, Su Thelen for remote data collection, and Andrea Wood for data analysis. Thanks go also to Shannon McDaniel, Shannon Electric, for installation of monitoring equipment. 


\section{Contents}

Preface $\ldots \ldots \ldots \ldots \ldots \ldots \ldots \ldots \ldots \ldots \ldots \ldots \ldots \ldots \ldots \ldots \ldots$ iii

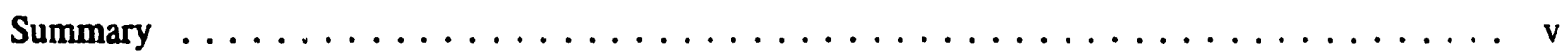

Acknowledgments $\ldots \ldots \ldots \ldots \ldots \ldots \ldots \ldots \ldots \ldots \ldots \ldots \ldots \ldots \ldots \ldots$

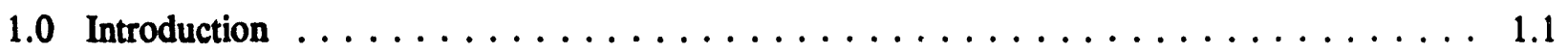

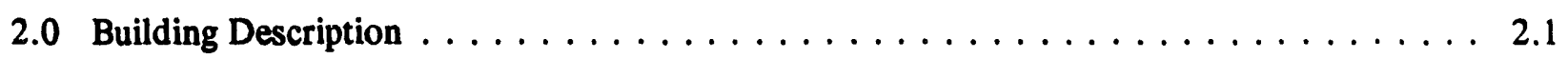

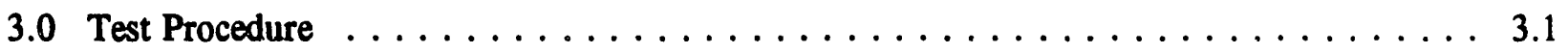

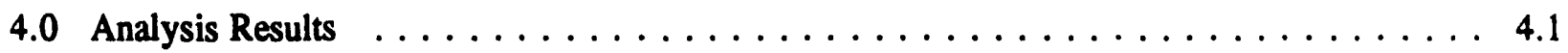

4.1 Gas Combustor Heat Rate Estimate $\ldots \ldots \ldots \ldots \ldots \ldots \ldots \ldots \ldots \ldots$

4.2 Heat Consumption Calculation $\ldots \ldots \ldots \ldots \ldots \ldots \ldots \ldots \ldots \ldots \ldots \ldots$

4.3 Regression Analysis $\ldots \ldots \ldots \ldots \ldots \ldots \ldots \ldots \ldots \ldots \ldots \ldots \ldots \ldots$

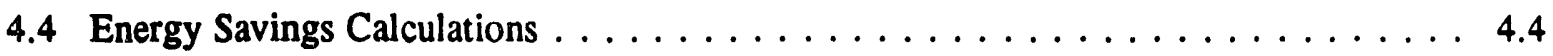

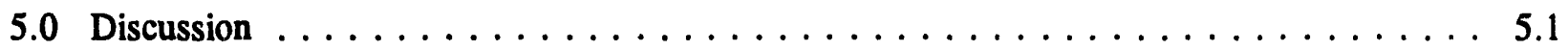

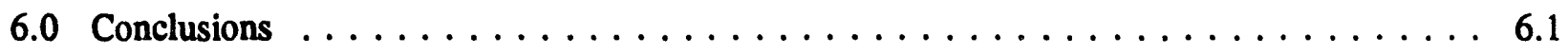




\section{Figures}

3.1 Typical Hourly Inside Temperatures for Building 1629

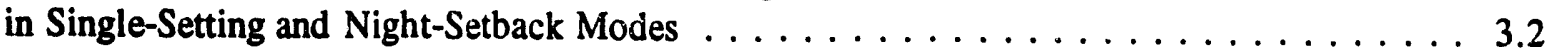

4.1 Correlation of Gas Valve On-Time and Gas Consumption $\ldots \ldots \ldots \ldots \ldots$

4.2 Regression Model for Calculating Mean Hourly Energy Savings . . . . . . . . . . . . 4.4

4.3 Seasonal Heating Consumption Estimates in Both

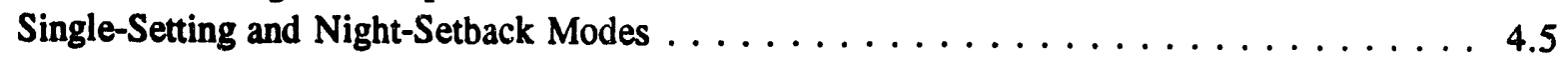

4.4 Seasonal Heating Consumption Estimates, Normalized to

$7^{\circ} \mathrm{F}$ Mean Inside Temperature (for Single-Setting Mode)

and $66^{\circ} \mathrm{F}$ Mean Inside Temperature (for Night-Setback Mode) $\ldots \ldots \ldots \ldots$

5.1 Seasonal Heating Cost Estimates in Both Single-Setting and

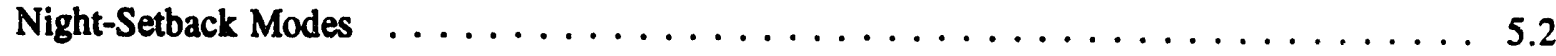

\section{Tables}

4.1 Gas Combustor Heat Rate Estimate Statistics $\ldots \ldots \ldots \ldots \ldots \ldots \ldots \ldots \ldots \ldots$

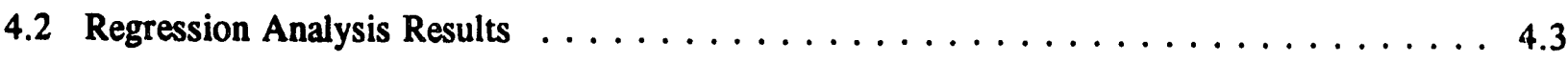




\subsection{Introduction}

During March 1990, the Fort Devens Directorate of Logistics (DOL) conducted a test to counter the popular misconception about nighttime temperature setback during the heating season--that the energy saved by lowering the temperature at night is lost when the building temperature is brought back up to comfortable levels during the day. To disprove this, two similar World War II-style twostory wooden administrative buildings, $4,720 \mathrm{ft}^{2}$ each, were selected for a short-term test. Recorders that measured run-time were wired into the forced-air heating system fan circuits at each building. The fan run-time measurements were used to estimate gas combustor on-time. The control building (Building 2203) was maintained at $70^{\circ} \mathrm{F}$, regardless of occupancy (single-setting). In the test building (Building 2204), the occupants manually controlled the thermostat to $70^{\circ} \mathrm{F}$ during occupied hours and to $55^{\circ} \mathrm{F}$ while unoccupied (night-setback). Both buildings were occupied 10 hours daily during a 24-hour test period. The recorded fan run-times for the control and the test buildings were 9 hours and 3.5 hours, respectively, indicating a potential $60 \%$ energy savings from use of nighttime temperature setback.

However, this result was questioned because of 1) uncertainties about similarities of building envelope and heating systems of the two apparently identical buildings; 2) possible differences between the fan and the combustor operating times; 3 ) relatively mild outside air temperatures during the 24-hour test period; 4) problems associated with extrapolation of the single 24-hour test results to seasonal performance; and 5) application of the night temperature setback. Fort Devens personnel requested an independent, detailed energy analysis to verify the annual energy savings and provide the incentive necessary to continue installation of night-setback thermostats in all similar buildings

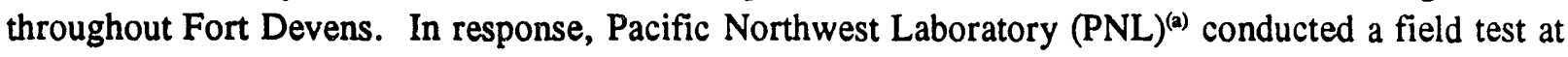
the Fort during the 1991-1992 winter to measure the energy savings resulting from the installation of automatic night-setback thermostats.

An overview of that field test is presented in this report. The buildings selected for the test are described in Section 2, followed by documentation of the test procedure in Section 3. In Section 4, the various analyses performed on the collected data are discussed, along with the results. Observations and conclusions drawn from the results are offered in Sections 5 and 6, respectively.

\footnotetext{
(a) Pacific Northwest Laboratory is operated by Battelle Memorial Institute for the U.S. Department of Energy under Contract DE-AC06-76RLO 1830.
} 


\subsection{Building Description}

Six "identical" two-story wooden structures, all currently used for administrative functions, were selected for this test. Each building has approximately 4,800 ft', and all were built circa 1941 . This type of construction is typical of approximately 200 buildings at Fort Devens and of many more throughout U.S. military installations.

Based on the condition of their envelopes, the six buildings were grouped into three classes as follows:

- Class I: Buildings 1628 and 1629 are the most recently renovated and are believed to be the most energy-efficient.

- Class II: Buildings 1620 and 1622 were apparently renovated 10 or more years ago, and appear to be moderately energy-efficient.

- Class III: Buildings 2285 and 2286 appear to be in much the same condition as when they were built-basically uninsulated wooden shells. They were expected to have the worst energy performance.

The mean occupancy in each varies widely, from 5 to 25 people, depending on the specific building and ongoing activities.

All six buildings are heated with gas-fired, forced-air furnaces. The furnace combustors are of similar types and heat ratings. The building temperatures are controlled by two thermostats. The main thermostat, which controls the furnace and was replaced with an automatic setback thermostat for this study, is located on the first floor. A second thermostat, located on the second floor, controls a damper that regulates the airflow rate into the second story. Without this two-zone control, the second story often becomes overheated on relatively warm, sunny days.

Identical automatic night-setback thermostats were installed in five of the buildings. The thermostat selected was designed to directly replace a conventional thermostat wired in a 24-volt control system. The electro-mechanical thermostat's features included a battery-powered solid-state clock, capability for multiple setback/setup time setpoints, two temperature setpoints (occupied/day and unoccupied/night periods), a temporary setback override for unexpected occupancy, and a very simple programming process. This thermostat does not have the capability of separate weekday/weekend setback settings.

More sophisticated microprocessor-controlled thermostats are commercially available. Additional features that should increase energy savings include more time and temperature setpoints, separate weekday/weekend schedules, and optimized start capability for automatic adjustment of setup time. The Fort Devens Directorate of Engineering and Housing (DEH) staff's informal evaluation of 
such thermostats indicated that their programming was too complicated and they were therefore not appropriate for general installations.

The 120 -volt control system in the sixth building, Building 1628, was not compatible with the 24-volt design limit of the thermostats. The occupants in this building were asked to manually adjust the thermostat temperature settings during the field test. 


\subsection{Test Procedure}

The six buildings were monitored during the period extending from 28 November 1991 to 31 March 1992. Field Data Acquisition System (FDAS) data loggers were then installed in each building. The FDAS is a stand-alone microprocessor-controlled data logger, developed at PNL, that is capable of processing electric power and analog and digital signals. The FDAS recorded a time series record (TSR) every integration period, which was selected as 1 hour for this test. Electric power and analog channel TSRs were based on a 2-second scan rate that is averaged for the integration period. The digital channel TSRs were an accumulated count of all pulses during the integration period. The TSRs recorded by the FDAS loggers were automatically downloaded to a computer at PNL via telephone modem on a daily basis.

The FDAS loggers recorded the following data channels for each building:

- gas valve (furnace) on-time, fraction of hour

- gas valve (furnace) on-cysles (number of times on), count per hour

- first floor inside air temperature, ${ }^{\circ} \mathrm{F}$

- second floor inside air temperature, ${ }^{\circ} \mathrm{F}$

- total (A + B phase) electric power, watts.

In addition, a pulse initiator was installed on an existing positive displacement gas meter on Building 1629 (originally installed for a previous test) to allow direct measurement of that building's gas consumption. The gas meter measurement resolution was $5 \mathrm{ft}^{3}$ of gas per pulse. No gas meters were available on the other five test buildings. These gas consumption measurements were used in the analysis to estimate the firing rate of the combustors in the furnaces of all six buildings.

Meteorological data were collected at Buildings 1629 and 2285. The data channels consisted of outside air temperature $\left({ }^{\circ} \mathrm{F}\right)$ and direct horizontal solar insolation $\left(\mathrm{W} / \mathrm{m}^{2}\right)$.

The number of times the gas valve turned on (on-cycles) and the amount of valve on-time were monitored to track gas consumption in the buildings without gas meters. Electric power data served as a proxy for building occupancy and as a measure of internal gains.

Although guidance was given to the building occupants regarding setback/setup time and temperature setpoints, specific setpoints were not mandated. Many occupants had expressed concern that a large night setback would leave the building uncomfortably cold for an extended period in the morning because the furnace would not have enough capacity to recover. And previous projects have shown that occupant comfort is critical to acceptance and continued long-term use of night setback. 
Therefore, each building's occupants were asked to use setback/setup setpoints with which they were comfortable, instead of the traditional $68^{\circ} \mathrm{F}$ occupied and $50^{\circ} \mathrm{F}$ unoccupied recommendations. All features, including both setback/setup times and temperature setpoints, were readily accessible to the building occupants at all times.

The thermostats were modified with electrical relays and telephone modem-based controllers that allowed the researchers to remotely select the single-setting or night-setback mode. The test design called for switching between single-setting or night-setback modes on a weekly basis throughout the heating season, without building occupant knowledge or participation. However, problems with the remote controllers required the occupants to actively participate in selecting or disabling night-setback operation during most of the test.

Temperature sensors were placed within 6 inches of each thermostat. Plots of inside temperatures were checked weekly to help ensure that building occupants were complying with the thermostat control mode. Figure 3.1 illustrates typical 24-hour temperature profiles for Building 1629 during both single-setting and night-setback modes.

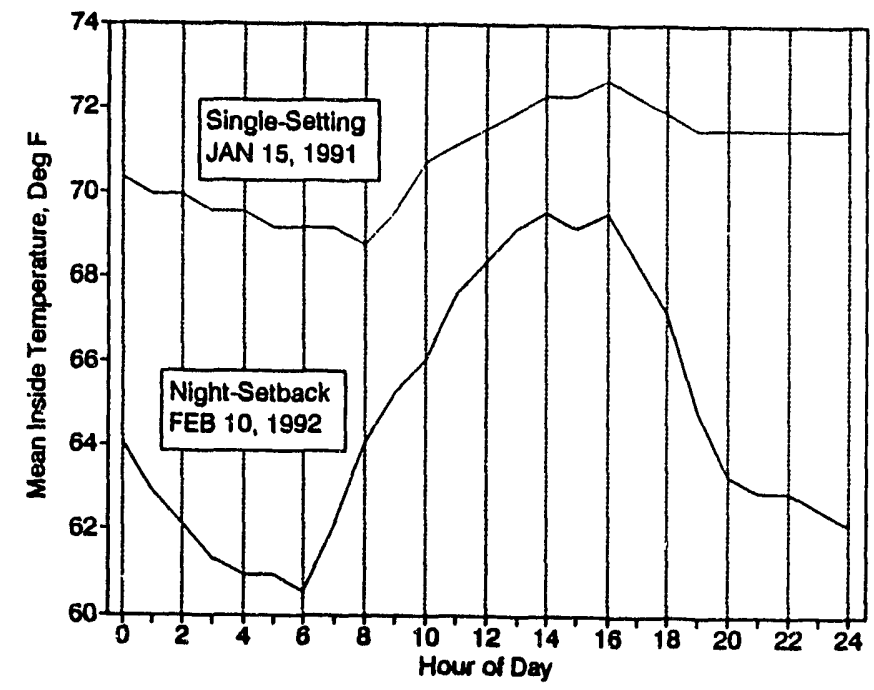

Figure 3.1. Typical Hourly Inside Temperatures for Building 1629 in Single-Setting and Night-Setback Modes 


\subsection{Analysis Results}

Four analyses were conducted on the data collected during the field test.

\subsection{Gas Combustor Heat Rate Estimate}

The first task in the analysis was to estimate the rate of gas consumption for the furnace combustors.

Gas consumption, based on the gas flow meter readings, was plotted against the furnace gas valve on-time for Building 1629, as shown in Figure 4.1. The resulting highly correlated linear relationship implies that the combustion rate for Builling 1629 was constant over the monitoring period.

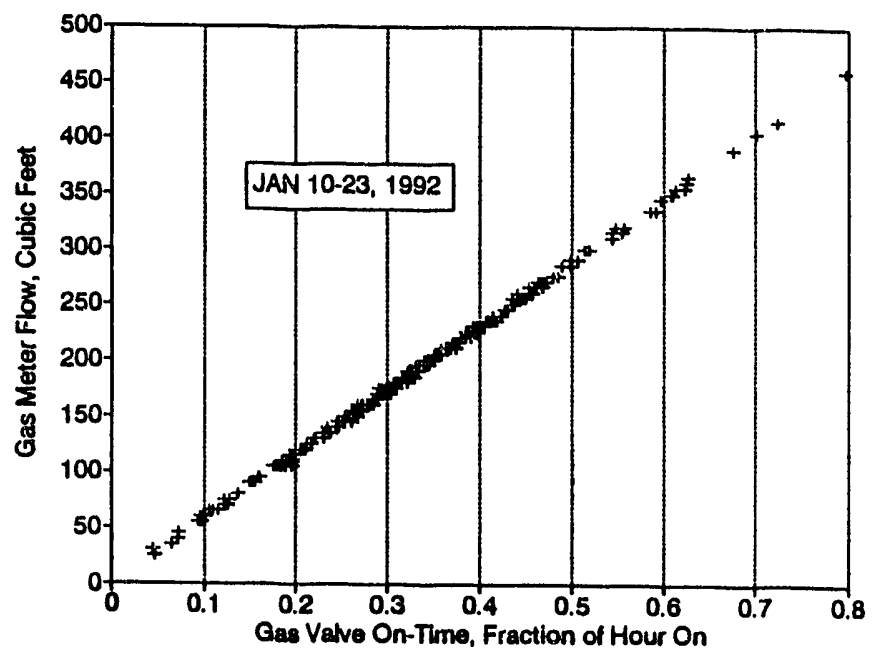

Figure 4.1. Correlation of Gas Valve On-Time and Gas Consumption

Given the measured gas consumption $\left(\mathrm{V}_{\cos }, \mathrm{ft}^{3}\right)$ and gas valve on-time $\left(\mathrm{t}_{\infty a}\right.$, hour), which were recorded as hourly integration period TSRs, and the average heat content of the gas $\left(\mathrm{H}_{z a}, 1030\right.$ $\left.\mathrm{Btu} / \mathrm{ft}^{3}\right)$, a fixed valued based on utility bills, the combustor heat rate $\left(\mathrm{Q}_{\mathrm{comb}}, \mathrm{Btu} / \mathrm{hr}\right)$ was calculated using

$$
Q_{c c m b}=\frac{V_{\text {gas }} \times H_{\text {gas }}}{t_{\text {on }}}
$$


A total of 2,944 TSRs were used to calculate hourly combustor heat rates. TSRs with no gas combustion were excluded from this calculation. All the hourly gas combustor heat rates were then averaged for the complete test period. The mean gas combustor heat rate and associated standard deviation are listed in Table 4.1.

Table 4.1. Gas Combustor Heat Rate Estim rte Statistics

\begin{tabular}{|l|l|}
\hline Mean & $619,398 \mathrm{Btu} / \mathrm{hr}$ \\
\hline Standard Deviation & $14,128 \mathrm{Btu} / \mathrm{hr}$ \\
\hline
\end{tabular}

\subsection{Heat Consumption Calculation}

The heat consumption calculation for Building 1629 was based on the gas volume measured by the installed gas flow meter. The hourly heat consumption for the building $\left(\mathrm{Q}_{\mathrm{bds}}, \mathrm{Btu} / \mathrm{hr}\right)$ is simply

$$
Q_{\text {bldg }}=V_{\text {gas }} \times H_{\text {gas }}
$$

Fr the remaining five buildings, which had no gas flow meters, the heat consumption was calculated using the mean combustion rate for Building 1629, as shown in Table 4.1, and the furnace on-time for each specific building:

$$
Q_{\text {bldg }}=619.398 \mathrm{Btu} / \mathrm{hr} \times t_{\text {on }}
$$

This is a reasonable assumption because the combustors in all six buildings were rated at similar heat rates and operated under similar conditions. Errors in absolute heat consumption do not affect each building's percent energy savings calculation, which is based on monitoring of each building during both single-setting and night-setback modes. Each building was used as its owin control.

\subsection{Regression Analysis}

The hourly values for heat consumption, electric power, direct solar horizontal insolation, inside temperature, and outside temperature were aggregated to create daily means for each measured variable. Scatter plots were then made of the daily mean heat consumption against each of the other measured quantities, as well as against the difference between the mean inside and mean outside temperatures (inside-outside $\Delta \mathrm{T}$ ). There was a significant difference between weekday and weekend 
heat consumption, and the inside-outside $\Delta \mathrm{T}$ variable was the one most highly correlated to heat consumption. These scatter plots were indicative of "typical" small- to medium-size, light- to medium-construction office buildings.

The daily mean data were then grouped according to day type (weekday and weekend/holiday). A least-squares linear regression against inside-outside $\Delta \mathrm{T}$ was then calculated for each group. The regression model used was

$$
Q_{b l d g}=a+b \times \Delta T_{1 n s 1 d \theta-o u t s 1 d \theta}
$$

where a, the intercept, is the heat consumption for equal inside and outside temperatures (insideoutside $\Delta \mathrm{T}$ equals zero), and $\mathrm{b}$, the slope, is the change in heat consumption for a 1-degree change in the inside-outside $\Delta T$. The regression results for each building, including the R-squared statistic and the number of days available for each regression, are summarized in Table 4.2.

Table 4.2. Regression Analysis Results

\begin{tabular}{|c|c|c|c|c|c|}
\hline Bldg & $\begin{array}{l}\text { Day } \\
\text { Type }\end{array}$ & $\begin{array}{c}\text { a } \\
\text { Btu/hr }\end{array}$ & $\begin{array}{c}\text { b } \\
(\mathrm{Btu} / \mathrm{hr}) /{ }^{\circ} \mathrm{F}\end{array}$ & R-squared & $\begin{array}{c}\text { Number } \\
\text { of } \\
\text { Days }\end{array}$ \\
\hline \multirow{2}{*}{1620} & Weekday & -44826 & 4645 & 0.852 & 77 \\
\hline & Weekend & -9550 & 4024 & 0.831 & 36 \\
\hline \multirow{2}{*}{1622} & Weekday & -34804 & 3516 & 0.659 & 58 \\
\hline & Weekend & -11520 & 3258 & 0.617 & 30 \\
\hline \multirow{2}{*}{1628} & Weekday & -19569 & 2100 & 0.729 & 80 \\
\hline & Weekend & -27826 & 2804 & 0.878 & 32 \\
\hline \multirow{2}{*}{1629} & Weekday & -61508 & 5696 & 0.892 & 86 \\
\hline & Weekend & -30668 & 5388 & 0.914 & 35 \\
\hline \multirow{2}{*}{2285} & Weekday & .22368 & 7030 & 0.646 & 74 \\
\hline & Weekend & -50183 & 8264 & 0.800 & 34 \\
\hline \multirow{2}{*}{2286} & Weekday & -74892 & 7694 & 0.862 & 77 \\
\hline & Weekend & -66799 & 7648 & 0.913 & 34 \\
\hline
\end{tabular}


Because the slope (b) is a function of the energy efficiency of the building envelope and heating system, the slope should be similar for both weekday and weekend day types. The nean difference was $11 \%$. Most of the difference car be explained by building envelope variations resulting from the frequency of door and window openings and application of window coverings.

The intercept (a) divided by the slope (b) represents the reduction in outside air temperature, as compared to the inside air temperature, before heating system operation is required. This outside air temperature is commonly called the balance point. Increased internal heat generation from equipment and people ("free" heat) during occupancy will result in a decreased balance point. As expected, the mean balance points measured were $8.8^{\circ} \mathrm{F}$ and $6.0^{\circ} \mathrm{F}$ below the inside air temperature for weekday and weekend periods, respectively.

\subsection{Energy Savings Calculations}

The daily mean data, already divided into weekday and weekend groups, were further subdivided by thermostat operation mode (i.e., single-setting or night-setback). The mean inside-outside $\Delta T$, over the monitoring period, was calculated for each of the four groups. These inside-outside $\Delta T s$ were then used in regression Equation (4.4) to estimate mean hourly weekday and weekend heat consumption for single-setting and night-setback thermostat operation.

Heating energy savings are a direct result of a lower mean inside operating temperature due to nighttime temperature setback. The difference between the mean single-setting inside-outside $\Delta \mathrm{T}$ and the mean night-setback inside-outside $\Delta \mathrm{T}$ (setback $\Delta \mathrm{T}$ ) is used to calculate the heating energy consumption savings, based on the Equation (4.4) regression. Figure 4.2 illustrates this process for Building 1629.

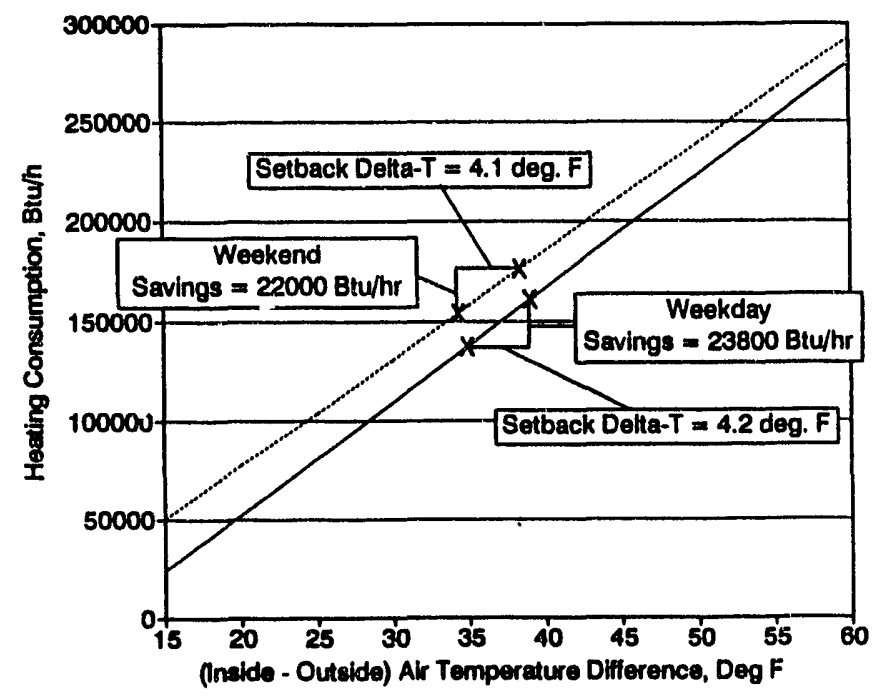

Figure 4.2. Regression Model for Calculating Mean Hourly Energy Savings 
The heating season weather conditions experienced during this test were representative of a typical winter at Fort Devens. The mean outside air temperature measured during the heating season (November 1991 through March 1992) at Fort Devens was $31.8^{\circ} \mathrm{F}$, compared to $35.4^{\circ} \mathrm{F}$ for Typical Meteorological Year (TMY) data for Boston, Massachusetts (the nearest city with available data). However, Fort Devens is located inland from Boston and has slightly cooler heating season temperatures.

Estimates of the seasonal consumption for single-setting and night-setback thermostat operation were then calculated. For each operational mode, the mean hourly consumption for the weekdays was multiplied by the number of weekdays in the season and 24 hours in the day. Similar calculations were performed for weekend conditions. The weekday and weekend consumptions were summed to obtain the estimate of seasonal consumption. Those estimates are summarized on the bar chart in Figure 4.3.

Also shown in Figure 4.3 are the percent savings associated with setback operation, and the mean, occupied and unoccupied inside air temperatures for each building. Most of the high inside temperatures were measured in the least energy-efficient buildings (Buildings 2285 and 2286). These temperatures probably reflect occupants' efforts to compensate for uncomfortable draft and cold wall conditions.

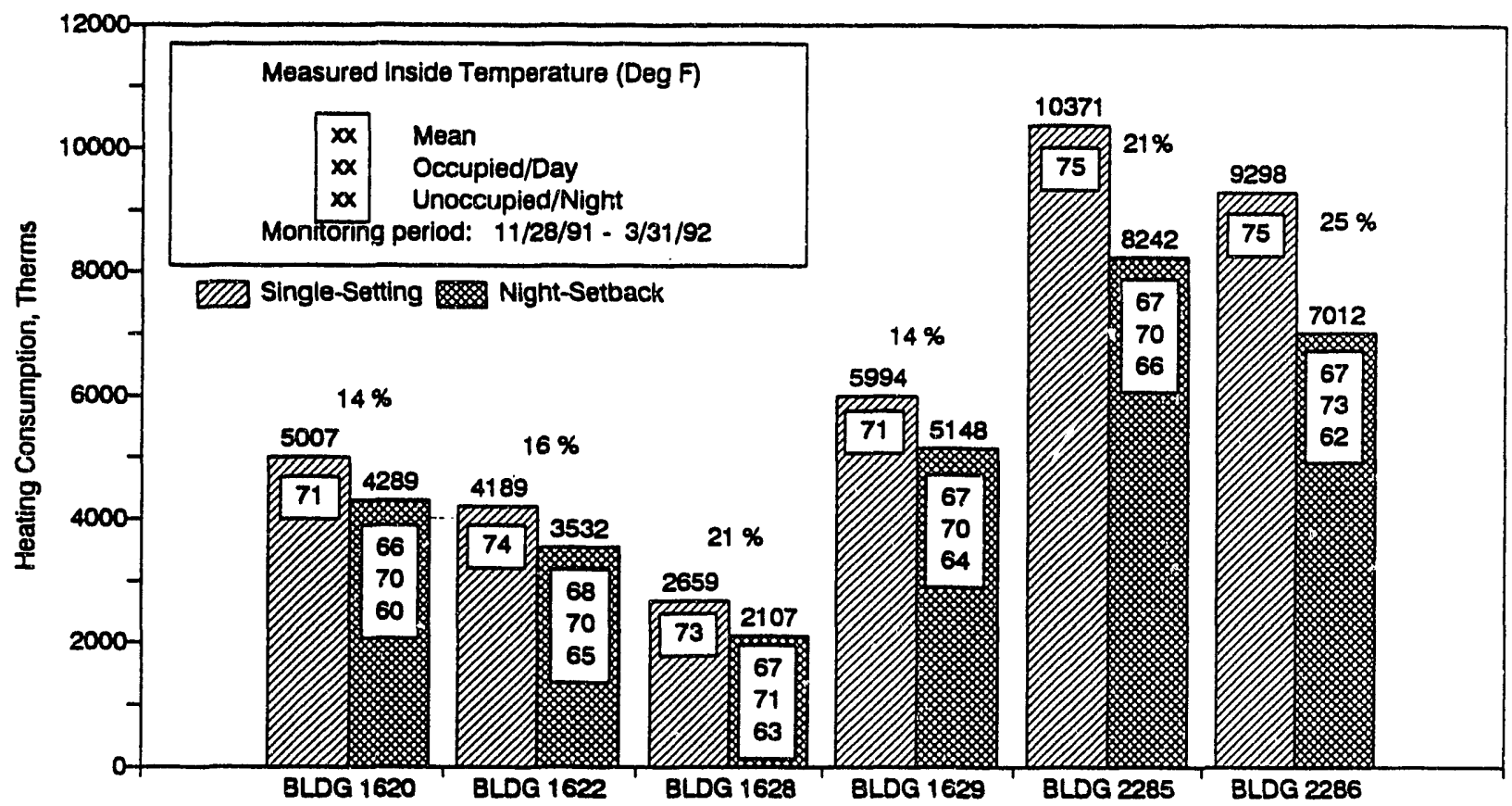

Figure 4.3. Seasonal Heating Consumption Estimates in Both Single-Setting and Night-Setback Modes 
Finally, the seasonal consumption estimates were normalized to the same mean inside temperatures for each building $\left(72^{\circ} \mathrm{F}\right.$ for the single-setting mode, $66^{\circ} \mathrm{F}$ for the setback mode). The results of those calculations are shown in Figure 4.4. This calculation removes the occupant effect with regard to variations in temperature setpoints.

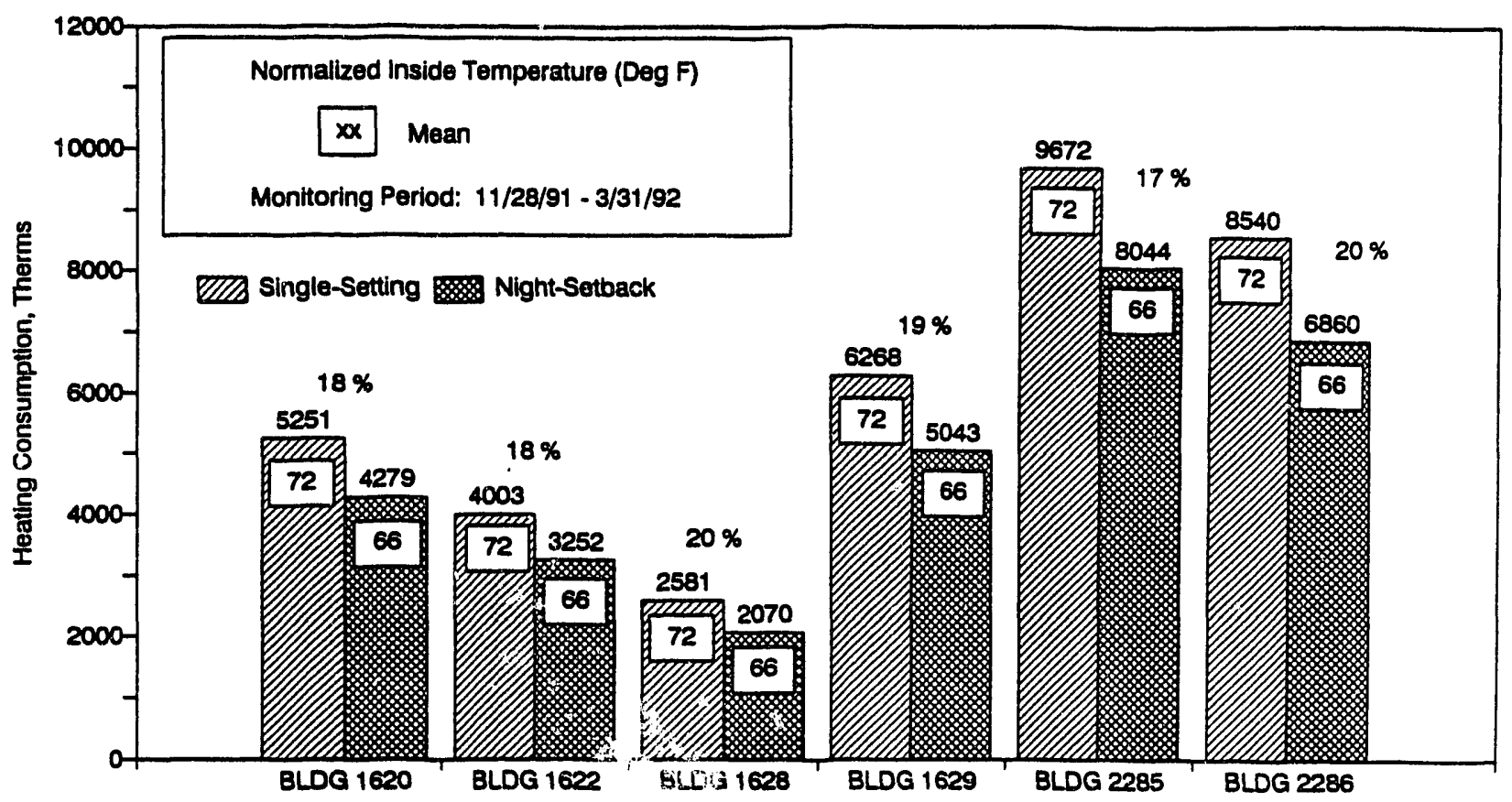

Figure 4.4. Seasonal Heating Consumption Estimates, Normalized to $72^{\circ} \mathrm{F}$ Mean Inside Temperature (for Single-Setting Mode) and $66^{\circ} \mathrm{F}$ Mean Inside Temperature (for Night-Setback Mode) 


\subsection{Discussion}

The measured energy savings resulting from using night temperature setback thermostats for the six Fort Devens buildings ranged from $14 \%$ to $25 \%$; the mean savings was $19.2 \%$. The mean seasonal energy consumption was 6,255 therm/year for single-setting and 5,055 therm/year for nightsetback. However, there is a 3.9-to-1 range of seasonal energy consumption, from 2,659 therm/year for the best building to 10,371 therm/year for the worst building. Even considering the mean of Class I and II, which included those recently renovated and those renovated 10 or more years ago, and Class III, those with virtually no insulation, there is a 2.2-to-1 range of seasonal energy consumption, from 4,462 therm/year for the better buildings to 9,835 therm/year for the worst buildings.

The difference between the two buildings within each building envelope class was $20 \%$ for Class I, $125 \%$ for Class II, and $11 \%$ for Class III. This means that for a night-setback test that selected two "identical" buildings--one as a control and the second as a test--the potential energy savings associated with the test building ranges from $11 \%$ to $125 \%$, even if night setback were not implemented. That was probably the main reason for the high $60 \%$ energy savings measured by DOL in the March 1990 Fort Devens nighttime-setback test. This problem was avoided in the PNL test by using the same building for both control (single-setting) and test (night-setback) modes.

The inside air temperature data indicated that the temperature setpoints of the thermostats were frequently changed by the occupants during the test period. Because the purpose of this test was to measure "realistic" energy savings, the occupants were not discouraged from setpoint modifications, as long as there was some temperature setback during the night-setback cycles of the test.

During the single-setting periods, the mean inside air temperature was $73^{\circ} \mathrm{F}$. During periods with night-setback, the mean inside air temperatures were $71^{\circ} \mathrm{F}$ during daytime and $64^{\circ} \mathrm{F}$ during nighttime--a mean setback of $7.3^{\circ} \mathrm{F}$. The daytime temperature decreased during night-setback periods, from $73^{\circ} \mathrm{F}$ to $71^{\circ} \mathrm{F}$, even with identical daytime thermostat temperature settings. This is a result of an early morning warmup period, which included most of the day in some buildings during cold days because the furnace did not have the capacity to quickly recover from night setback.

Building 1628 was one of the best in terms of energy efficiency, which typically results in a lower energy savings percentage. But its energy savings percentage was as high as that of Building 2285 , one of the worst. Unlike the remaining buildings, the manually operated temperature setback in Building 1628 (an automatic setback thermostat could not be installed) remained set back all weekend. In the buildings with automatic setback thermostats, the setpoint was automatically set up during the day on weekends, even though the buildings were unoccupied. This finding suggests that additional savings ( $7 \%$ in this case) could be realized by installing thermostats "smarter" than those used in this test. 
Based on a cost of $\$ 0.65 /$ therm of natural gas, the estimated average savings in energy costs is $\$ 780$ per year per building. The annual energy costs for single-setting and night-setback modes and the annual energy cost savings for each of the six buildings are shown in Figure 5.1. The mean energy cost savings from use of heating season night setback ranged from a high of $\$ 1485 /$ year for the worst building to $\$ 359 /$ year for the best building. The mean of the Class III buildings was $\$ 1435 /$ year, compared to the four better buildings, Class I and II, at \$450/year--a 2.2-to-1 range.

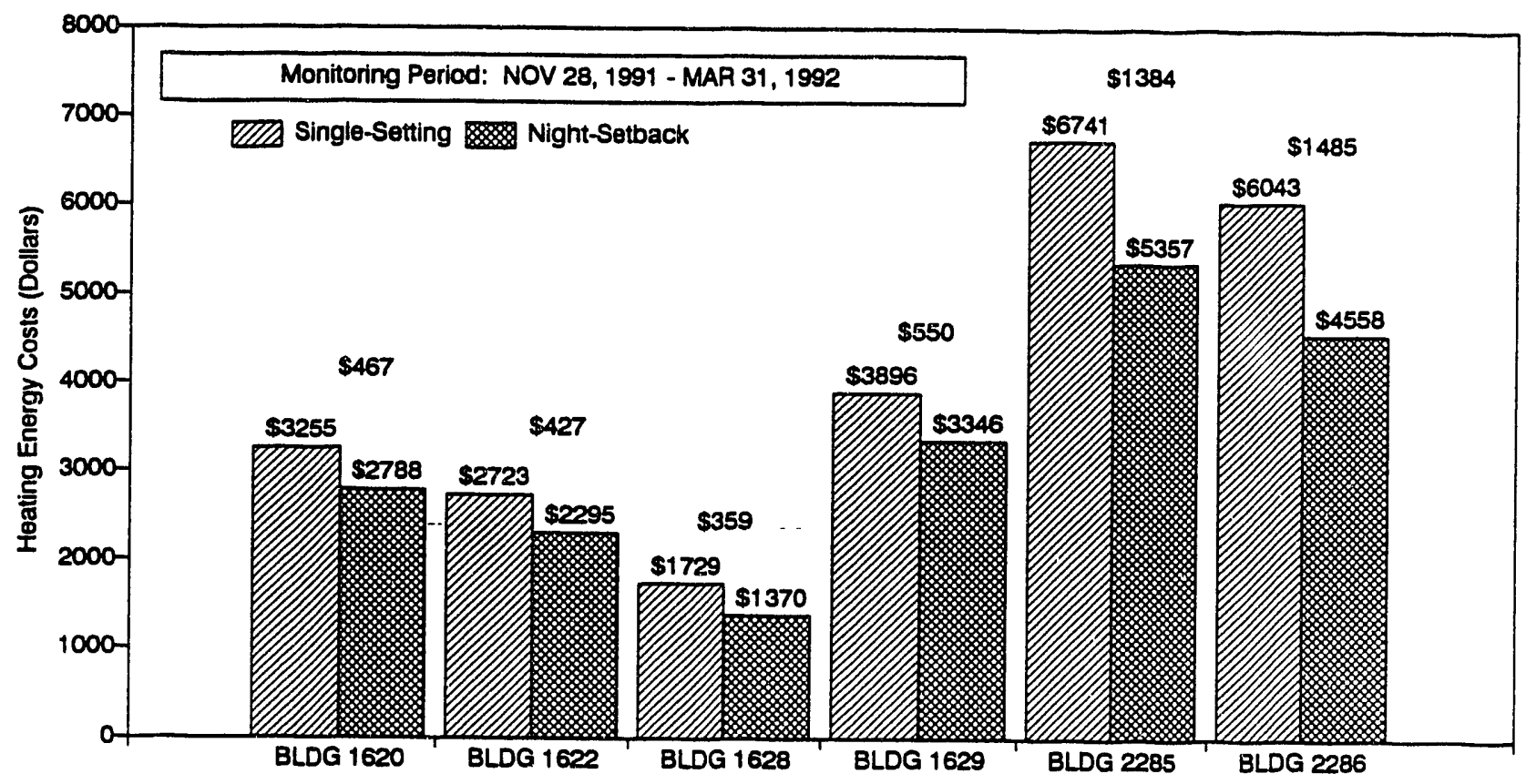

Figure 5.1. Seasonal Heating Cost Estimates in Both Single-Setting and Night-Setback Modes 


\subsection{Conclusions}

The energy savings measured in this study are "real," repeatable in other similar buildings, and of long-term persistence. The reason is that the setback/setup time and temperature setpoints were selected by the building occupants based on their respective building's heating system characteristics and their personal comfort range. Many other projects have demonstrated that mandated time and temperature setpoints, which do not allow for individual variations in occupancy patterns, heating system recovery rates, local temperature variations, and variations in peoples' comfort range, will eventually be disregarded-resulting in less-than-predicted energy savings.

The measured energy savings resulting from use of heating season nighttime temperature setback in six two-story wooden office buildings at Fort Devens was $19.2 \%$. The associated average energy cost savings is $\$ 780$ per year per building. The simple payback time is less than one month of the heating season, based on a $\$ 100$ cost for purchase and installation of a simple automatic setback thermostat.

Although the $\$ 450 /$ year energy cost savings associated with the four better buildings is economically attractive, the $\$ 1435 /$ year energy cost savings associated with the worst buildings indicates that a priority should be set for installation of automatic setback thermostats in the worst buildings first.

Purchase and installation of night-setback thermostats is cost-effective for all similar office buildings that are going to be occupied for more than one month of the next heating season. For a $\$ 20,000$ investment, application of night setback to the 200 similar buildings at Fort Devens will yield cost savings of approximately $\$ 150,000$ per year for natural gas. Because the heat loss mechanisms are common to most small-to-medium office buildings, similar energy savings can also be expected for a much wider range of buildings. 


\section{Distribution}

No. of

Copies

Offsite

2 DOE/Office of Scientific and Technical Communication

2 A. Gillespie

Headquarters Forces Command

FCEN-RDF

Building 200

Fort McPherson, GA $30330-6000$

2 B. Starling

U.S. Army Corps of Engineers

Huntsville Division

CEHND/ED/ME

P.O. Box 1600

Huntsville, AL 35807

2 J. B. Paton

Office of the Secretary of Defense

DASD (L) EP

The Pentagon

Washington, DC 20301-8000

K. D. Devine

Federal Energy Management Program

U.S. Department of Energy

CE-10.1

6A-034/FORS

1000 Independence Avenue SW

Washington, DC 20585

P. J. O'Neill

Sensor and System Development Center Honeywell, Inc.

3660 Technology Drive, MN65-2750

Minneapolis, MN 55418
No. of

Copies

Onsite

Department of Energy Richland Field Office

D. R. Segna

17 Pacific Northwest Laboratory

R. Bartlett

D. J. Coomes (2)

A. J. Currie

J. W. Currie

D. L. Dixon

G. B. Parker

R. W. Reilly

W. F. Sandusky

R. F. Szydlowski

L. E. Wrench

Publishing Coordination

Technical Report Files (5) 

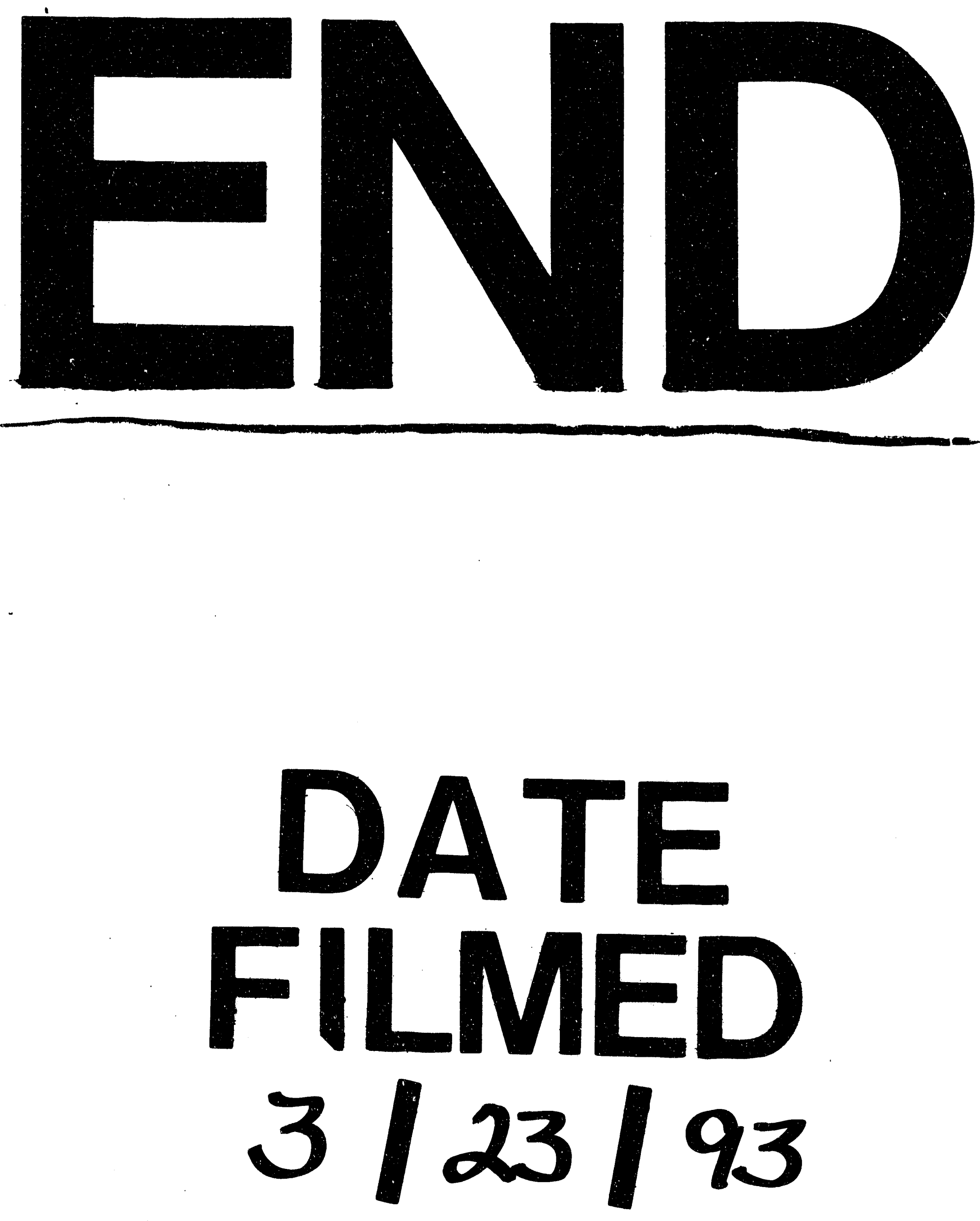
